\title{
Are Ancestral Medical Practices the Future Solution to Today's Medical Problems?
}

\author{
José A. Lupiáñez ${ }^{1, * \mathbb{D}}$, Eva E. Rufino-Palomares ${ }^{1, * \mathbb{D}}$ and Amalia Pérez-Jiménez ${ }^{2, *(\mathbb{D})}$ \\ 1 Department of Biochemistry and Molecular Biology I, Faculty of Sciences, University of Granada, \\ Avenida Fuentenueva, 118071 Granada, Spain \\ 2 Department of Zoology, Physiology and Ecology, Faculty of Sciences, University of Granada, \\ Avenida Fuentenueva, 118071 Granada, Spain \\ * Correspondence: jlcara@ugr.es (J.A.L.); evaevae@ugr.es (E.E.R.-P.); calaya@ugr.es (A.P.-J.); \\ Tel.: +34-958-243089 (J.A.L.); +34-958-243252 (E.E.R.-P.); +34-958-249843 (A.P.-J.); \\ Fax: +34-958-249945 (J.A.L. \& E.E.R.-P. \& A.P.-J.)
}

check for updates

Citation: Lupiáñez, J.A.; Rufino-Palomares, E.E.; Pérez-Jiménez, A. Are Ancestral Medical Practices the Future Solution to Today's Medical Problems? Molecules 2021, 26, 4701. https:// doi.org/10.3390/molecules26154701

Received: 29 July 2021

Accepted: 2 August 2021

Published: 3 August 2021

Publisher's Note: MDPI stays neutral with regard to jurisdictional claims in published maps and institutional affiliations.

Copyright: (C) 2021 by the authors. Licensee MDPI, Basel, Switzerland. This article is an open access article distributed under the terms and conditions of the Creative Commons Attribution (CC BY) license (https:/ / creativecommons.org/licenses/by/ $4.0 /)$.
Our cells and organs are threatened and, in most cases, constantly subjected to the aggression of numerous situations, both endogenous, characterized by unfavorable genetics, and exogenous, by deficient or inadequate nutrition, and even by a hostile environment; in most cases, they ultimately cause a cascade of degenerative and cardiovascular diseases, cancer, and infections, as well as those related to the metabolic syndrome, all of which eventually generate irreversible damage to the organism and, consequently, a significant deterioration in its survival. In many of these cases, exogenous treatment with essential biocomponents present in numerous species, mainly plants, can reverse this deterioration and, therefore, increase survival.

The year 2020 marked a millennium since the publication of the two books that laid the foundations of modern and current medicine-the volumes entitled, The Book of Healing and The Canon of Medicine, the latter commonly known as the "Avicenna Codex." Both books were published between 1014 and 1020 by the Persian Muslim physician, polymath, philosopher, scientist, and astronomer Abū 'Alī al-Husayn ibn' Abd Allāh ibn Sĩnã, better known as Ibn Sina and westernized as Avicenna, as well as the "Prince of the Sages," the greatest of physicians, the Master par excellence, or the Third Master (after Aristotle and Al-Farabi). Although it is evident that Avicenna put into practice the first principles of surgery, his greatest contribution was the use of the main natural chemical components, derived from the plant and animal (kingdoms?) world, to achieve the cure of the most important diseases of the time as described in the second book of the Avicenna Codex, entitled De Medicinis Simplicibus: Pharmacologicae de Herbis Medicinalibus, which deals with the pharmacology of medicinal herbs and is intended for the study and use of natural medicines [1]. However, we must recognize that numerous types of plasters formed from plant extracts have been mainly used by humankind practically from the Metal Age (6000 BC-3300 BC) until almost the end of the Modern Age (1492 AD-1789 AD) and have been especially important in the development of the different traditional medicines of different cultures, both for Western and, especially, for Oriental medicines.

At present, and especially since the last 20 years, there is a real explosion in the search for natural chemical compounds, generally known as "phytochemicals," from the plant (kingdom?) world, both terrestrial and aquatic, capable of presenting important and abundant biological properties. The so-called phytochemicals are chemical compounds produced by many botanical species and which play an important role in the growth of the plant species themselves and also as participants in the defense against competitors, pathogens, or predators. The word "phytochemical" has been generally used to describe a number of botanical compounds that are being investigated for their effects on health, and many of them are being used both as drugs, in different traditional medicines, and also as poisons [2]. 
Among the enormous variety of phytochemicals currently characterized, we can find flavonoids, such as anthocyanins, flavones, flavanones, and flavanols (catechins, epicatechins, etc.), phytosterols, terpenoids, lignans, and stilbenes, the last two being considered an excellent source of polyphenols such as resveratrol [3]. All of them have been recognized with a large number of bioactive effects as nutraceuticals, essential nutrients, and even allelopathic, thus influencing the growth, survival, or reproduction of other organisms [4]. Among all these phytochemicals, several should be highlighted, namely, terpenoids and polyphenols, of which consequential research related to their bioactive capacities both in vitro and in vivo is being carried out [5]. Many of these compounds have properties such as anticancer, using different cancer lines, both solid and liquid [6-11], antiangiogenic [7,12-15], antioxidant [16-18], anti-inflammatory [19,20], cardio- and neuroprotective [21,22], antidiabetogenic [23,24], antifungal [25], antimicrobial and antiviral [26,27], antiparasitic [28], growth inducing [29-31], and enzyme inhibitory or activating [32,33], as well as modulators in the production of reducing equivalents whose role is essential to explain most of the processes of metabolic biosynthesis [34], of cellular and organic growth, nutrition and differentiation processes [35-38] as well as, of cellular detoxification processes [39] and oxygen-free radical scavenging [18,40].

Currently, special emphasis is put on the search for a great variety of chemical derivatives of all these phytochemicals, finding in many cases a significant increase in the different bioactive capacities with respect to those of the original compound [5]. Numerous chemical groups are being used in the synthesis of chemical derivatives of the most important triterpenoids in order to select derivatives that present a significant increase in efficiency in their bioactivity. Among them, acyl, aminoacyl, and dipeptidyl groups [26,27,41,42], pegylated and pegylated diamine derivatives [43-46], and even coumarin conjugates [47] stand out. In all cases, the anticancer, anti-inflammatory, antioxidant, or antiviral effects originally present in the molecules from which they are obtained are significantly increased.

This Special Issue entitled Anticancer properties of natural products and derivatives, (https://www.mdpi.com/journal/molecules/special_issues/anticancer_np, accessed on 30 November 2020), has tried to expose part of the works currently carried out in the field of natural products and their bioactivities, mainly anticancer, to the scientific world. It consists of a total of 15 publications, of which 11 are original articles and 4 are bibliographic reviews. All of them cover very different topics, both in terms of the type of active components or nutraceuticals and the organic source that provides them.

Propolis is a resinous mixture collected opportunistically by honeybees from various plant sources, such as tree buds, sap exudates, or other sources, which is then processed within the hive for use as a sealant for small holes to prevent infection. Although it has been used as a traditional and folk medicine for several millennia, numerous biological properties of propolis have recently been described, including cytotoxic, antiviral, antimicrobial, and antioxidant activities that promote the scavenging of oxygen free radicals (ROS) [48]. In this regard, Wezgowiec et al. [49] have studied the chemical composition and anticancer and anti-inflammatory activities, in vitro, of ethanolic and ethanol-hexane extracts of propolis from different Polish regions on tongue cancer cells (SCC-25). High concentrations of polyphenols and flavonoids seem to be responsible for these biological activities and for the differences between the activities of propolis from different locations. Administration of these extracts produced, among other effects, a significant reduction in mitochondrial and proliferative activity, together with a clear modification of oxygen-free radical scavenging activity. All these effects indicate a selective anticancer and anti-inflammatory potential, although, as the authors indicate, further study of the molecular mechanisms that explain this is necessary to obtain promising health benefits.

Adenosma bracteosum (Bonati) is a plant belonging to the group of tracheophytes, mainly present in the Southeast Asian region and whose extracts have been used in traditional Vietnamese medicine to cure liver diseases. The main active groups present are polyphenols, terpenoids, and flavonoids. Recently, ethanolic extracts have been shown to have significant antidiabetogenic activity [50]. In this context, Nguyen et al. [51] have 
analyzed the anticancer capacity of the different fractions derived from the ethanolic extract of this tracheophyte, using two cancer cell lines, one for lung carcinoma (NCI-H460) and the other for liver carcinoma (HepG2). Of all the fractions, the chloroform-derived one seems to be the most active being the active principles that provide this bioactivity are flavonoids, xantomicrol, and its oxygenated derivative, together with the triterpene, ursolic acid. Its most significant activities focus on modulating free radical levels and mitochondrial membrane potential. All these activities, together with potent cytotoxic activity, seem to be responsible for an increase in the levels and therefore the activity of caspase-3, which is ultimately responsible for the increase in cell apoptosis, suggesting that this plant offers a good opportunity to develop new anticancer drugs.

On many occasions, continuous treatment with radioactivity and chemotherapy to different types of cancer, in certain patients, can cause adverse side effects that, on too many occasions, generate great resistance to specific drugs in these tumors; therefore, it is necessary to find more effective and, mainly, less invasive pharmacological treatments. Moringa oleifera is a tree native to northern India for which important nutritional and pharmacological functions have been described, such as anti-inflammatory, antihypertensive, diuretic, hepatoprotective, hypocholesterolemic, antispasmodic, antiulcer, and antibacterial [52]. In this context, Luetragoon et al. [53] have investigated the anticancer effects of an active principle, 3-hydroxy- $\beta$-ionone, a sesquiterpenoid present in extracts of Moringa oleifera leaves. These authors have demonstrated the in vitro anticancer capacity of this compound in epidermoid carcinoma of the head and neck (SCC-15), by detecting cell cycle arrest in the $\mathrm{G}_{2} / \mathrm{M}$ phase and a significant increase in cell apoptosis, thanks to an increase in caspase-3 levels, together with a decrease in the anti-apoptotic protein Bcl-2 and profound inhibition of cell migration after $6 \mathrm{~h}$ of treatment.

Among the active compounds present in the fruit and leaf of the olive tree (Olea europaea L.), the pentacyclic triterpenes stand out, along with, mainly due to their content, maslinic acid, of which a large number of beneficial health effects have been demonstrated on many occasions [5,8-10,16,29-32]. One of the most controversial functions of maslinic acid is its antioxidant capacity; thus, Mokhtari et al. [18] investigated this property in murine cutaneous melanoma cells (B16F10). In addition to the known selective cytotoxic effects of maslinic acid on cancer cells, it was also demonstrated that after provoking an oxidative stress situation by the addition of hydrogen peroxide $\left(\mathrm{H}_{2} \mathrm{O}_{2}\right)$, the triterpene isolated from the olive tree protected tumor cells from concomitant oxidative damage by decreasing ROS levels and modifying the activities of different antioxidant enzymes such as superoxide dismutase (SOD), glutathione S-transferase (GST), and glutathione peroxidase (GPX), thus demonstrating a high antioxidant capacity of this triterpene and therefore its beneficial effects on health.

Elaeagnus angustifolia, commonly called paradise tree or Bohemian olive, is a shrub native to the Middle East whose floral extracts have been traditionally used to treat many diseases in that area. In their article, Jabeen et al. [54] reveal that flower extracts from the paradise tree were able to inhibit in vitro cell proliferation and modify cell cycle progression in two breast cancer lines (SKBR3 and ZR75-1) positive for the human epidermal growth factor receptor 2 (HER2) protein; furthermore, these extracts inhibited epithelialmesenchymal transition (EMT), an important event for cancer invasion and metastasis, by increasing the levels of E-cadherin and $\beta$-catenin and inhibiting those of vimentin and fascin, as main marker molecules of cell invasiveness. Furthermore, these authors demonstrate the chemopreventive effects of these extracts by blocking HER2 activities and inactivating the $\mathrm{JNK} / 1 / 2 / 3$ signaling pathway.

As we have stated in this article, natural products play an important role in the development of new nutraceuticals that help to prevent and cure diseases, and in this sense, the triterpenes present in the olive tree (Olea europaea L.) are very relevant. An example of these compounds is uvaol, and a practically innovative study of this active principle was carried out by Bonel-Pérez et al. [15], in which they analyzed its anticancer and antimetastatic effects in vitro in a hepatocarcinoma cell line (HepG2). These authors 
show the main molecular responsible for these activities, focusing their study on the levels of the heat shock protein HSP60, on the levels of ROS, as well as those of the antiapoptotic Bcl2 and proapoptotic Bax proteins, together with a cellular arrest in the $G_{0} / G_{1}$ phase and downregulation of the AKT/PI3K and MAPK signaling pathway. These results constitute an interesting challenge in the treatment of this type of cancer.

Another important source of active ingredients, which are increasingly used in conventional oncology, are the so-called medicinal mushrooms, and although they act by interfering with tumor cells, disrupting both the development and progression of the disease, the mechanisms of action that cause this have yet to be elucidated. Roda et al. [55], using triple negative $4 \mathrm{~T} 1$ mice administered in vivo with a mixture of these medicinal mushrooms, observed a significant reduction in both tumor density and the number of metastatic bodies, showing at the same time a decrease in inflammation and oxidative stress, both in the primary tumor and in metastases. These extraordinary effects molecularly implicate the $\mathrm{p} 53$ /Bax versus Bcl2/PARP1/PCNA axis, forcing triple-negative breast cancer cells into apoptosis.

Pogostemon cablin, commonly known as patchouli, is a plant from which essential oil is extracted from the leaves, rich in sesquiterpenes, which has been used as an antiseptic since ancient times in Asia; in addition, its use as a pharmaceutical product prevents or cures various side effects such as fever, headache, pain, and inflammation. Other studies have revealed different bioactivities, such as antimicrobial and antiviral, anti-inflammatory, anti-aging, and antitumor. Therefore, Huang et al. [56] have investigated the in vitro and in vivo response of human hepatoma cells (HepG2 and MAHLAVU) to treatment with the essential oils of this plant. The in vitro antiproliferative effects are explained by the existence of high cytotoxicity, a cell arrest in $\mathrm{G}_{0} / \mathrm{G}_{1}$, together with an increase of apoptosis, both extrinsic and intrinsic, a decrease of the mitochondrial membrane potential, and a modulation of the Akt/mTOR pathway. In in vivo studies, they used BALB/c nude mice as a xenograft model, demonstrating that the administration of these essential oils suppressed tumor growth, owing to a significant reduction of the VEGF/VEGFR axis and an induction of apoptosis in tumor cells, prolonging the life of the mice.

Lactucoprim is a sesquiterpene lactone, a component of lactucarium, a milky liquid extracted from the wild lettuce, Lactuca virosa. It is also used as a sedative and analgesic. Its antiproliferative activity on $\mathrm{U} 87 \mathrm{Mg}$ glioblastoma cells in vitro has been analyzed by Rotondo et al. [57]. In addition to a potent cytotoxic effect and cell cycle arrest in $\mathrm{G}_{2} / \mathrm{M}$, lactucoprim administration showed a significant reduction in cell growth and migration, as well as activation of autophagy. All these findings, together with an increase in apoptosis, owing to a decrease in procaspase- 6 levels, an increase in PARP, and its positive participation in oxidative stress, allow us to affirm that lactucoprim can be considered as a promising adjuvant therapy in the treatment of this disease.

In the wild jungles of Costa Rica grow a large number of fungi that contain a large number of molecules with antitumor capacity. One of them, Macrocybe titans, contains a triacylglyceride called macrocybin, (which?) whose structure includes oleic acid, palmitic acid, and a more complex fatty acid with two double bonds. Using this active principle, Vilariño et al. [58] studied its anticancer activity in a xenograft with A549 tumors, achieving a significant reduction in tumor growth and a positive regulation of caveolin-1 expression, which explains the disassembly of the actin cytoskeleton in tumor cells.

The following article presents an example of how many of the chemical derivatives of a natural compound could increase both the ability to move specifically to their target and their biological activity. Grymel et al. [59] have synthesized, through the copper-catalyzed 1,3-dipolar azide-alkyne (CuAAC) cycloaddition reaction, new betulin derivatives with monosaccharides via a linker containing a heteroaromatic 1,2,3-triazole ring. These authors tested the in vitro cytotoxicity of all these derivatives using two cancer cell lines, one for human breast carcinoma (MCF-7) and the other for colorectal carcinoma (HCT-116). The main finding of this work is that the idea of adding sugar units to the betulin structure allows an optimized specific transfer of the glycoconjugate to the tumor cells. 
Although, for now, we cannot consider phytochemicals and their metabolites as essential nutrients in humans, the fact is that more and more research, and a good example is this Special Issue, strongly links the fact that their intake leads to greater prevention of many diseases, including cancer. In this sense, in their article, Ferraz da Costa et al. [60] review both the molecular mechanisms of grape and red wine bioactive compounds and their metabolites in breast cancer, as well as chemoprevention and its treatment. It is very interesting to note the approach taken, relating the structure of the different compounds, flavonoids, monomeric catechins, proanthocyanidins, anthocyanins, anthocyanidins, and non-flavonoid phenolic compounds, such as resveratrol, to their metabolism and especially to their bioavailability. The review also includes an excellent discussion of in vitro, in vivo, and clinical trials on chemoprevention and therapy with these molecules.

Traditionally, chemotherapy and radiotherapy have been used in the treatment of cancer; however, it is necessary to discover new treatments that, on the one hand, are less aggressive for the organism and, on the other hand, more specific in order to recognize and differentiate tumor cells from those that are not. Possibly one of these novel treatments to eliminate different types of cancer is photodynamic therapy (PDT). The main requirement of this type of therapy is the use of photosensitizers (PS) and photoactivation using a specific wavelength of light in the presence of molecular oxygen. The combined action of these two elements is capable of exerting a cascade of molecular actions that end up modulating processes such as apoptosis, necrosis, and autophagy in tumor cells. Photoactive substances derived from medicinal plants have been shown to be safe in comparison with synthetic compounds, and although more and more natural compounds are being discovered that exhibit photosensitizing potential, it is necessary to continue along this path to find new, more active molecules that cover a broader spectrum. In this regard, Muniyandi et al. [61], in their review, put special emphasis on the importance of common photoactive groups (furanocoumarins, polyacetylenes, thiophenes, curcumin, alkaloids, and anthraquinones), their phototoxic effects, their anticancer activity, and their use as a potent PS to achieve an effective PDT result in the treatment of various types of cancers. Another review related to the use of photosensitizing compounds is presented by Verebová et al. [62]. These authors provide a comprehensive summary of the physical and chemical properties of photosensitizers of the hypericin type and their model composed of emodin, quinizarin, and danthron, and show us important antiviral, antifungal, antineoplastic and antitumor effects. They conclude their work by stating that these compounds can be used as potential agents in photodynamic therapy, especially in cancer therapy.

Following the common pattern of synthesizing chemical derivatives of natural molecules in the search for more biologically effective compounds, Professor Csuk's group [63] has screened and reviewed several triterpenoid derivatives of rhodamine. This compound belongs to a group of fluorescents, xanthene-based, fluorescein-derived, heterocyclic organic molecules that have traditionally been used as dyes and amplifying substances in dye lasers. In their study, these authors reveal the degree of cytotoxicity of these derivatives, all of which exhibit a low nanomolar range, combined with good tumor/non-tumor selectivity. The studies indicate that the homopiperazinyl spacer is more effective than the piperazinyl spacer, which allows them to state that the use of a homopiperazinyl spacer can be considered a promising candidate in biological studies.

As mentioned in this article, more and more new natural compounds with greater efficacy and biological selectivity are being sought, and all of us who form part of the medical-scientific community hope that some can be incorporated into the list of effective drugs that serve to save lives, especially at this time, when a pandemic such as COVID-19 is seriously affecting humanity, although much more severely in those countries with crucial problems in obtaining vaccines, but which, possibly, may have greater possibilities of obtaining these types of drugs. For all the contributions, we are deeply grateful for the effort and collaboration of all the authors who have made it possible, with their articles, to make this Special Issue a reality. 
Author Contributions: Writing—original draft preparation, J.A.L.; Writing-review and editing. J.A.L., E.E.R.-P., and A.P.-J. All authors have agreed to the last version. All authors have read and agreed to the published version of the manuscript.

Funding: This work did not receive external funding.

Institutional Review Board Statement: Not applicable.

Informed Consent Statement: Not applicable.

Data Availability Statement: Not applicable.

Acknowledgments: The authors thank Alejandro L. Lupiáñez for the critical revision of the English version of the text.

Conflicts of Interest: The authors declare that they have no conflict of interest.

\section{References}

1. Al-Husayn, I.A.I.S. De Pharmacologicae de Herbis Medicinalibus. In Avicenna Canon Medicinae, (Manuscript ms 2197), 2nd ed.; University Library of Bologna: Bologna, Italy, 1988; Volume 1020, pp. 156-416.

2. Molyneux, R.J.; Lee, S.T.; Gardner, D.R.; Panter, K.E.; James, L.F. Phytochemicals: The good, the bad and the ugly? Phytochemistry 2007, 68, 2973-2985. [CrossRef]

3. Dinkova-Kostova, A. Phytochemicals as Protectors against Ultraviolet Radiation: Versatility of Effects and Mechanisms. Planta Medica 2008, 74, 1548-1559. [CrossRef] [PubMed]

4. Gill, A.S.; Prasad, J.V.N.S. Allelopathic interactions in agroforestry systems. Allelopath. Ecol. Agric. For. 2000, 13, 195-207. [CrossRef]

5. Rufino-Palomares, E.E.; Pérez-Jiménez, A.; Reyes-Zurita, F.J.; García-Salguero, L.; Mokhtari, K.; Herrera-Merchán, A.; Medina, P.P.; Peragón, J.; Lupiáñez, J.A. Anti-cancer and Anti-angiogenic Properties of Various Natural Pentacyclic Tri-terpenoids and Some of their Chemical Derivatives. Curr. Org. Chem. 2015, 19, 919-947. [CrossRef]

6. Reyes-Zurita, F.J.; Centelles, J.J.; Lupiáñez, J.A.; Cascante, M. (2 $\alpha, 3 \beta)$-2,3-Dihydroxyolean-12-en-28-oic acid, a new natural triterpene from Olea europea, induces caspase dependent apoptosis selectively in colon adenocarcinoma cells. FEBS Lett. 2006, 580, 6302-6310. [CrossRef]

7. Laszczyk, M.N. Pentacyclic Triterpenes of the Lupane, Oleanane and Ursane Group as Tools in Cancer Therapy. Planta Medica 2009, 75, 1549-1560. [CrossRef]

8. Rufino-Palomares, E.E.; Reyes-Zurita, F.J.; García-Salguero, L.; Mokhtari, K.; Medina, P.P.; Lupiáñez, J.A.; Peragón, J. Maslinic acid, a triterpenic anti-tumoural agent, interferes with cytoskeleton protein expression in HT29 human colon-cancer cells. J. Proteom. 2013, 83, 15-25. [CrossRef]

9. Sánchez-Tena, S.; Reyes-Zurita, F.J.; Diaz-Moralli, S.; Vinardell, M.P.; Reed, M.; Garcia-Garcia, F.; Dopazo, J.; Lupiáñez, J.A.; Günther, U.; Cascante, M. Maslinic Acid-Enriched Diet Decreases Intestinal Tumorigenesis in ApcMin/+ Mice through Transcriptomic and Metabolomic Reprogramming. PLoS ONE 2013, 8, e59392. [CrossRef]

10. Reyes-Zurita, F.J.; Rufino-Palomares, E.E.; Medina, P.P.; García-Salguero, L.; Peragón, J.; Cascante, M.; Lupiáñez, J.A. Antitumour activity on extrinsic apoptotic targets of the triterpenoid maslinic acid in p53-deficient Caco-2 adenocarcinoma cells. Biochimie 2013, 95, 2157-2167. [CrossRef]

11. Reyes-Zurita, F.J.; Rufino-Palomares, E.E.; García-Salguero, L.; Peragón, J.; Medina, P.P.; Parra, A.; Cascante, M.; Lupiáñez, J.A. Maslinic Acid, a Natural Triterpene, Induces a Death Receptor-Mediated Apoptotic Mechanism in Caco-2 p53-Deficient Colon Adenocarcinoma Cells. PLoS ONE 2016, 11, e0146178. [CrossRef]

12. Chintharlapalli, S.; Papineni, S.; Ramaiah, S.K.; Safe, S. Betulinic Acid Inhibits Prostate Cancer Growth through Inhibition of Specificity Protein Transcription Factors. Cancer Res. 2007, 67, 2816-2823. [CrossRef] [PubMed]

13. Lin, C.-C.; Huang, C.-Y.; Mong, M.-C.; Chan, C.-Y.; Yin, M.-C. Antiangiogenic Potential of Three Triterpenic Acids in Human Liver Cancer Cells. J. Agric. Food Chem. 2011, 59, 755-762. [CrossRef]

14. Shanmugam, M.K.; Dai, X.; Kumar, A.P.; Tan, B.K.; Sethi, G.; Bishayee, A. Oleanolic acid and its synthetic derivatives for the prevention and therapy of cancer: Preclinical and clinical evidence. Cancer Lett. 2014, 346, 206-216. [CrossRef] [PubMed]

15. Bonel-Pérez, G.C.; Pérez-Jiménez, A.; Gris-Cárdenas, I.; Parra-Pérez, A.; Lupiáñez, J.; Reyes-Zurita, F.J.; Siles, E.; Csuk, R.; Peragón, J.; Rufino-Palomares, E.E. Antiproliferative and Pro-Apoptotic Effect of Uvaol in Human Hepatocarcinoma HepG2 Cells by Affecting G0/G1 Cell Cycle Arrest, ROS Production and AKT/PI3K Signaling Pathway. Molecules 2020, 25, 4254. [CrossRef] [PubMed]

16. Montilla, M.P.; Agil, A.; Navarro, M.C.; Jiménez, M.I.; García-Granados, A.; Parra, A.; Cabo, M.M. Antioxidant Activity of Maslinic Acid, a Triterpene Derivative Obtained from Olea europaea. Planta Medica 2003, 69, 472-474. [CrossRef]

17. Mokhtari, K.; Rufino-Palomares, E.E.; Pérez-Jiménez, A.; Reyes-Zurita, F.J.; Figuera, C.; García-Salguero, L.; Medina, P.P.; Peragón, J.; Lupiáñez, J.A. Maslinic Acid, a Triterpene from Olive, Affects the Antioxidant and Mitochondrial Status of B16F10 Melanoma Cells Grown under Stressful Conditions. Evid. Based Complement. Altern. Med. 2015, 2015, 1-11. [CrossRef] 
18. Mokhtari, K.; Pérez-Jiménez, A.; García-Salguero, L.; Lupiáñez, J.A.; Rufino-Palomares, E.E. Unveiling the Differential Antioxidant Activity of Maslinic Acid in Murine Melanoma Cells and in Rat Embryonic Healthy Cells Following Treatment with Hydrogen Peroxide. Molecules 2020, 25, 4020. [CrossRef] [PubMed]

19. Marquez-Martin, A.; De La Puerta, R.; Fernandez-Arche, A.; Ruiz-Gutierrez, V.; Yaqoob, P. Modulation of cytokine secretion by pentacyclic triterpenes from olive pomace oil in human mononuclear cells. Cytokine 2006, 36, 211-217. [CrossRef] [PubMed]

20. Zhang, X.; Cao, J.; Zhong, L. Hydroxytyrosol inhibits pro-inflammatory cytokines, iNOS, and COX-2 expression in human monocytic cells. Naunyn Schmiedeberg's Arch. Pharmacol. 2009, 379, 581-586. [CrossRef]

21. Qian, Y.; Guan, T.; Tang, X.; Huang, L.; Huang, M.; Li, Y.; Sun, H. Maslinic acid, a natural triterpenoid compound from Olea europaea, protects cortical neurons against oxygen-glucose deprivation-induced injury. Eur. J. Pharmacol. 2011, 670, 148-153. [CrossRef]

22. Shaik, A.H.; Rasool, S.; Kareem, M.A.; Krushna, G.S.; Akhtar, P.M.; Devi, K.L. Maslinic Acid Protects Against IsoproterenolInduced Cardiotoxicity in Albino Wistar Rats. J. Med. Food 2012, 15, 741-746. [CrossRef]

23. Khathi, A.; Serumula, M.R.; Myburg, R.B.; Van Heerden, F.; Musabayane, C.T. Effects of Syzygium aromaticum-Derived Triterpenes on Postprandial Blood Glucose in Streptozotocin-Induced Diabetic Rats Following Carbohydrate Challenge. PLoS ONE 2013, 8, e81632. [CrossRef] [PubMed]

24. Pérez-Jiménez, A.; Rufino-Palomares, E.E.; Fernández-Gallego, N.; Ortuño-Costela, M.C.; Reyes-Zurita, F.J.; Peragón, J.; GarcíaSalguero, L.; Mokhtari, K.; Medina, P.P.; Lupiáñez, J.A. Target molecules in 3T3-L1 adipocytes differentiation are regulated by maslinic acid, a natural triterpene from Olea europaea. Phytomedicine 2016, 23, 1301-1311. [CrossRef] [PubMed]

25. Sultana, N.; Ata, A. Oleanolic acid and related derivatives as medicinally important compounds. J. Enzym. Inhib. Med. Chem. 2008, 23, 739-756. [CrossRef]

26. Parra, A.; Martin-Fonseca, S.; Rivas, F.; Reyes-Zurita, F.J.; Medina-O’Donnell, M.; Martinez, A.; García-Granados, A.; Lupiáñez, J.A.; Albericio, F. Semi-synthesis of acylated triterpenes from olive-oil industry wastes for the development of anticancer and anti-HIV agents. Eur. J. Med. Chem. 2014, 74, 278-301. [CrossRef]

27. Medina-O’Donnell, M.; Rivas, F.; Reyes-Zurita, F.J.; Cano-Muñoz, M.; Martinez, A.; Lupiáñez, J.A.; Parra, A. Oleanolic Acid Derivatives as Potential Inhibitors of HIV-1 Protease. J. Nat. Prod. 2019, 82, 2886-2896. [CrossRef] [PubMed]

28. Moneriz, C.; Mestres, J.; Bautista, J.M.; Diez, A.; Puyet, A. Multi-targeted activity of maslinic acid as an antimalarial natural compound. FEBS J. 2011, 278, 2951-2961. [CrossRef] [PubMed]

29. Fernández-Navarro, M.; Peragón, J.; Amores, V.; De La Higuera, M.; Lupiáñez, J.A. Maslinic acid added to the diet increases growth and protein-turnover rates in the white muscle of rainbow trout (Oncorhynchus mykiss). Comp. Biochem. Physiol. Part. C Toxicol. Pharmacol. 2008, 147, 158-167. [CrossRef]

30. Rufino-Palomares, E.E.; Reyes-Zurita, F.J.; Fuentes-Almagro, C.; De La Higuera, M.; Lupiáñez, J.A.; Peragón, J. Proteomics in the liver of gilthead sea bream (Sparus aurata) to elucidate the cellular response induced by the intake of maslinic acid. Proteomics 2011, 11, 3312-3325. [CrossRef]

31. Rufino-Palomares, E.; Reyes-Zurita, F.; García-Salguero, L.; Peragón, J.; De La Higuera, M.; Lupiáñez, J.A. Maslinic acid, a natural triterpene, and ration size increased growth and protein turnover of white muscle in gilthead sea bream (Sparus aurata). Aquac. Nutr. 2012, 18, 568-580. [CrossRef]

32. Reyes-Zurita, F.J.; Rufino-Palomares, E.E.; Lupiáñez, J.A.; Cascante, M. Maslinic acid, a natural triterpene from Olea europaea L., induces apoptosis in HT29 human colon-cancer cells via the mitochondrial apoptotic pathway. Cancer Lett. 2009, $273,44-54$. [CrossRef]

33. Reyes-Zurita, F.J.; Pachón-Peña, G.; Lizárraga, D.; Rufino-Palomares, E.E.; Cascante, M.; Lupiáñez, J.A. The natural triterpene maslinic acid induces apoptosis in HT29 colon cancer cells by a JNK-p53-dependent mechanism. BMC Cancer 2011, 11, 154. [CrossRef]

34. Barroso, J.B.; García-Salguero, L.; Peragón, J.; De la Higuera, M.; Lupiáñez, J.A. The influence of dietary protein on the kinetics of NADPH production systems in various tissues of rainbow trout (Oncorhynchus mykiss). Aquaculture 1994, 124, 47-59. [CrossRef]

35. Lupiáñez, J.A.; Adroher, F.J.; Vargas, A.M.; Osuna, A. Differential behaviour of glucose 6-phosphate dehydrogenase in two morphological forms of Trypanosoma cruzi. Int. J. Biochem. 1987, 19, 1085-1089. [CrossRef]

36. Adroher, F.J.; Osuna, A.; Lupiáñez, J.A. Differential energetic metabolism during Trypanosoma cruzi differentiation. II. Hexokinase, phosphofructokinase and pyruvate kinase. Mol. Cell. Biochem. 1990, 94, 71-82. [CrossRef]

37. Sánchez-Muros, M.J.; García-Rejón, L.; Lupiáñez, J.A.; De la Higuera, M. Long-term nutritional effects on the primary liver and kidney metabolism in rainbow trout (Oncorhynchus mykiss). II. Adaptive response of glucose 6-phosphate dehydrogenase activity to high-carbohydrate/low-protein and high-fat/non-carbohydrate diets. Aquac. Nutr. 1996, 2, 193-200. [CrossRef]

38. Barroso, J.B.; Peragón, J.; García-Salguero, L.; De la Higuera, M.; Lupiáñez, J.A. Carbohydrate deprivation reduces NADPHproduction in fish liver but not in adipose tissue. Int. J. Biochem. Cell Biol. 2001, 33, 785-796. [CrossRef]

39. Sheehan, D.; Meade, G.; Foley, V.M.; Dowd, C.A. Structure, function and evolution of glutathione transferases: Implications for classification of non-mammalian members of an ancient enzyme superfamily. Biochem. J. 2001, 360, 1-16. [CrossRef] [PubMed]

40. Corpas, F.J.; Barroso, J.B.; Sandalio, L.M.; Palma, J.M.; Lupiáñez, J.A.; del Río, L.A. Peroxisomal NADP-Dependent Isocitrate Dehydrogenase. Characterization and Activity Regulation during Natural Senescence. Plant. Physiol. 1999, 121, 921-928. [CrossRef] 
41. Parra, A.; Martin-Fonseca, S.; Rivas, F.; Reyes-Zurita, F.J.; Medina-O'Donnell, M.; Rufino-Palomares, E.E.; Martínez, A.; GarciaGranados, A.; Lupiáñez, J.A.; Albericio, F. Solid-Phase Library Synthesis of Bi-Functional Derivatives of Oleanolic and Maslinic Acids and Their Cytotoxicity on Three Cancer Cell Lines. ACS Comb. Sci. 2014, 16, 428-447. [CrossRef]

42. Reyes-Zurita, F.J.; Medina-O'Donnell, M.; Ferrer-Martin, R.M.; Rufino-Palomares, E.E.; Martin-Fonseca, S.; Rivas, F.; Martínez, A.; García-Granados, A.; Pérez-Jiménez, A.; García-Salguero, L.; et al. The oleanolic acid derivative, 3-O-succinyl-28-O-benzyl oleanolate, induces apoptosis in B16-F10 melanoma cells via the mitochondrial apoptotic pathway. RSC Adv. 2016, 6, 93590-93601. [CrossRef]

43. Medina-O'Donnell, M.; Rivas, F.; Reyes-Zurita, F.J.; Martinez, A.; Martin-Fonseca, S.; Garcia-Granados, A.; Ferrer-Martín, R.M.; Lupiáñez, J.A.; Parra, A. Semi-synthesis and antiproliferative evaluation of PEGylated pentacyclic triterpenes. Eur. J. Med. Chem. 2016, 118, 64-78. [CrossRef] [PubMed]

44. Medina-O'Donnell, M.; Rivas, F.; Reyes-Zurita, F.J.; Martinez, A.; Galisteo-González, F.; Lupiáñez, J.A.; Parra, A. Synthesis and in vitro antiproliferative evaluation of PEGylated triterpene acids. Fitoterapia 2017, 120, 25-40. [CrossRef] [PubMed]

45. Medina-O'Donnell, M.; Rivas, F.; Reyes-Zurita, F.J.; Martinez, A.; Lupiáñez, J.A.; Parra, A. Diamine and PEGylated-diamine conjugates of triterpenic acids as potential anticancer agents. Eur. J. Med. Chem. 2018, 148, 325-336. [CrossRef]

46. Jannus, F.; Medina-O’Donnell, M.; Rivas, F.; Díaz-Ruiz, L.; Rufino-Palomares, E.E.; Lupiáñez, J.A.; Parra, A.; Reyes-Zurita, F.J. A Diamine-PEGylated Oleanolic Acid Derivative Induced Efficient Apoptosis through a Death Receptor and Mitochondrial Apoptotic Pathway in HepG2 Human Hepatoma Cells. Biomolecules 2020, 10, 1375. [CrossRef] [PubMed]

47. Vega-Granados, K.; Medina-O'Donnell, M.; Rivas, F.; Reyes-Zurita, F.J.; Martinez, A.; Álvarez de Cienfuegos, L.; Lupiáñez, J.A.; Parra, A. Synthesis and Biological Activity of Triterpene-Coumarin Conjugates. J. Nat. Prod. 2021, 84, 1587-1597. [CrossRef]

48. Toreti, V.C.; Sato, H.H.; Pastore, G.M.; Park, Y.K. Recent Progress of Propolis for Its Biological and Chemical Compositions and Its Botanical Origin. Evid. Based Complement. Altern. Med. 2013, 2013, 1-13. [CrossRef]

49. Wezgowiec, J.; Wieczynska, A.; Wieckiewicz, W.; Kulbacka, J.; Saczko, J.; Pachura, N.; Wieckiewicz, M.; Gancarz, R.; Wilk, K.A. Polish Propolis-Chemical Composition and Biological Effects in Tongue Cancer Cells and Macrophages. Molecules 2020, 25, 2426. [CrossRef]

50. Nguyen, N.H.; Pham, Q.T.; Luong, T.N.H.; Le, H.K.; Vo, V.G. Potential Antidiabetic Activity of Extracts and Isolated Compound from Adenosma bracteosum (Bonati). Biomolecules 2020, 10, 201. [CrossRef]

51. Nguyen, N.H.; Ta, Q.T.H.; Pham, Q.T.; Luong, T.N.H.; Phung, V.T.; Duong, T.H.; Vo, V.G. Anticancer Activity of Novel Plant Extracts and Compounds from Adenosma bracteosum (Bonati) in Human Lung and Liver Cancer Cells. Molecules 2020, $25,2912$. [CrossRef]

52. Anwar, F.; Latif, S.; Ashraf, M.; Gilani, A. Moringa oleifera: A food plant with multiple medicinal uses. Phytother. Res. 2006, 21, 17-25. [CrossRef]

53. Luetragoon, T.; Sranujit, R.P.; Noysang, C.; Thongsri, Y.; Potup, P.; Suphrom, N.; Nuengchamnong, N.; Usuwanthim, K. AntiCancer Effect of 3-Hydroxy- $\beta$-Ionone Identified from Moringa oleifera Lam. Leaf on Human Squamous Cell Carcinoma 15 Cell Line. Molecules 2020, 25, 3563. [CrossRef]

54. Jabeen, A.; Sharma, A.; Gupta, I.; Kheraldine, H.; Vranic, S.; Al Moustafa, A.-E.; Al Farsi, H.F. Elaeagnus angustifolia Plant Extract Inhibits Epithelial-Mesenchymal Transition and Induces Apoptosis via HER2 Inactivation and JNK Pathway in HER2-Positive Breast Cancer Cells. Molecules 2020, 25, 4240. [CrossRef] [PubMed]

55. Roda, E.; De Luca, F.; Locatelli, C.A.; Ratto, D.; Di Iorio, C.; Savino, E.; Bottone, M.G.; Rossi, P. From a Medicinal Mushroom Blend a Direct Anticancer Effect on Triple-Negative Breast Cancer: A Preclinical Study on Lung Metastases. Molecules 2020, 25, 5400. [CrossRef] [PubMed]

56. Huang, X.F.; Sheu, G.T.; Chang, K.F.; Huang, Y.C.; Hung, P.H.; Tsai, N.M. Pogostemon cablin Triggered ROS-Induced DNA Damage to Arrest Cell Cycle Progression and Induce Apoptosis on Human Hepatocellular Carcinoma In Vitro and In Vivo. Molecules 2020, 25, 5639. [CrossRef] [PubMed]

57. Rotondo, R.; Oliva, M.A.; Staffieri, S.; Castaldo, S.; Giangaspero, F.; Arcella, A. Implication of Lactucopicrin in Autophagy, Cell Cycle Arrest and Oxidative Stress to Inhibit U87Mg Glioblastoma Cell Growth. Molecules 2020, 25, 5843. [CrossRef] [PubMed]

58. Vilariño, M.; García-Sanmartín, J.; Ochoa-Callejero, L.; López-Rodríguez, A.; Blanco-Urgoiti, J.; Martínez, A. Macrocybin, a Natural Mushroom Triglyceride, Reduces Tumor Growth In Vitro and In Vivo Through Caveolin-Mediated Interference with the Actin Cytoskeleton. Molecules 2020, 25, 6010. [CrossRef]

59. Grymel, M.; Pastuch-Gawołek, G.; Lalik, A.; Zawojak, M.; Boczek, S.; Krawczyk, M.; Erfurt, K. Glycoconjugation of Betulin Derivatives Using Copper-Catalyzed 1,3-Dipolar Azido-Alkyne Cycloaddition Reaction and a Preliminary Assay of Cytotoxicity of the Obtained Compounds. Molecules 2020, 25, 6019. [CrossRef] [PubMed]

60. Ferraz da Costa, D.C.; Rangel, L.P.; Quarti, J.; Santos, R.A.; Silva, J.L.; Fialho, E. Bioactive Compounds and Metabolites from Grapes and Red Wine in Breast Cancer Chemoprevention and Therapy. Molecules 2020, 25, 3531. [CrossRef] [PubMed]

61. Muniyandi, K.; George, B.; Parimelazhagan, T.; Abrahamse, H. Role of Photoactive Phytocompounds in Photodynamic Therapy of Cancer. Molecules 2020, 25, 4102. [CrossRef] [PubMed]

62. Verebová, V.; Beneš, J.; Staničová, J. Biophysical Characterization and Anticancer Activities of Photosensitive Phytoanthraquinones Represented by Hypericin and Its Model Compounds. Molecules 2020, 25, 5666. [CrossRef] [PubMed]

63. Hoenke, S.; Serbian, I.; Deigner, H.P.; Csuk, R. Mitocanic Di- and Triterpenoid Rhodamine B Conjugates. Molecules 2020, $25,5443$. [CrossRef] [PubMed] 